\title{
Perception of Millennial Generation of Farmer Children on Employment in Agricultural Sectors (Case Study of Farmer Children in Village Padang Cekur, Talo District, Seluma District)
}

\author{
Eko Sumartono $^{1, \mathrm{a}, \# \text {, Ellys Yuliarti }}{ }^{1, \mathrm{~b}} \&$ Dewi Stopia Nengsi ${ }^{1, \mathrm{c}}$ \\ ${ }^{1}$ Departement Agriculture Socio-EconomicFaculty of Agriculture, University of Bengkulu, Indonesia \\ e-mail: a\# eko_sumartono@unib.ac.id; b dewistopianengsi44@gmail.com \\ \#Corresponding Author \\ Whatsapp Number $\{+62-82138129668\}$
}

\section{ARTICLE HISTORY}

Received: 20 March 2019

Revised: 28 April 2019

Accepted: 26 June 2019

Copyright @ 2019 Authors \& Published by IIES Independent. This is an open-access article distributed under the terms of the CC-BY-SA License.

\begin{abstract}
Millennials are the largest or the largest generation in Indonesia and their births are marked by explosive use of technology, in Indonesia this generation is at least 237.6 million and 34 percent of the total population is millennial. Based on BPS data, the number of workers in the agricultural sector dropped sharply from 42.28 million people in February 2011 to as many as 39.96 million people in February 2012, this was like what was found in the millennial generation in Padang Cekur Village, Ilir Talo District, Seluma District. The purpose of this study was to analyze perceptions and analyze the factors that influence the perceptions of the millennial generation of peasant children in Padang Cekur Village, Ilir Talo District, Seluma District for employment in the agricultural sector. Data from this study were tested using non-parametric statistical tests through Chi-Square test. Both variables are said to be related if the test result value ( $p$ value) is smaller than the value of $\alpha$ (alpha). From the results of the study showed that the Perception of Millennial Generation of peasant children in Padang Cekur Village, Ilir Talo District, Seluma District on employment in the agricultural sector was negative, due to lack of motivation given by respondents' parents to agricultural work and due to the expectation of parents of respondents his child works outside the agricultural sector. Factors that influence the millennial generation towards the perception of employment in the agricultural sector are skills, work experience, family socio-economic status, job socialization, and cosmopolitan level.
\end{abstract}

Keywords: Millennial Generation; Technology; Labor; Perception; Agriculture

How to Cite: Sumartono, E., Yuliarti, E., \& Nengsi, D.S., (2019). Perception of Millennial Generation of Farmer Children on Employment in Agricultural Sectors (Case Study of Farmer Children in Village Padang Cekur, Talo District, Seluma District). International Journal of Advances in Social and Economics, 1(1), 22-27.

\section{Introduction}

Millennials are generally the children of the older Baby Boomers and Gen-X generations. Millennials are sometimes referred to as "Echo Boomers" because of the "boom" (large increase) in birth rates in the 1980s and 1990s. (Baby Boom Population, 2008). This generation is generally characterized by increased use and familiarity with communication, media, and digital technology.

Indonesia is the fourth largest population in the world after China, India and the United States. The populat- ion in Indonesia according to BPS in 2010 reached 237.6 million and of the total population, 34 percent were millennials, the population was $18-38$ years old. This age is a very prime age for humans and at that age people usually enter the workforce.

The problem that has not been resolved in the world of employment in Indonesia is the problem of unemployment. Unemployment is someone who belongs to a group of working-age population who, during a certain period, do not work, and are willing 
to accept work, and are looking for work (BPS 2010). In line with this, the Ministry of Manpower and Transmigration (2012) states that the number of open unemployed people who are looking for work in Indonesia is high, namely $7,244,956$ people and 40 percent of them are high school graduates or equivalent.

From the data of residents working in the agricultural sector in 2008-2012, the data shows that there has been a significant decline in the number of people working in this sector in recent years. Prihatmoko (2013) stated that based on BPS data the number of workers in the agricultural sector dropped sharply from 42.28 million people in February 2011 to as many as 39.96 million people in February 2012. This indicates that labor in Indonesia began to shift to many sectors outside agriculture. Can be seen in the graph of the percentage of labor in the agricultural sector below.

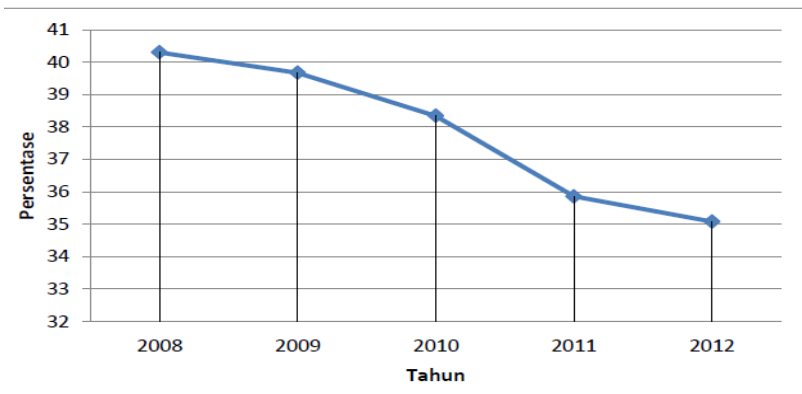

Source: Dioalah from Ministry of Manpower and Transmigration data 2008-2012

Figure 1. Percentage of population working in the agricultural sector

Today's millennial village generation has left many agricultural jobs, seen by their efforts to apply in various other employment sectors and experience multiple job changes outside the agricultural sector. The millennial generation that does this is still in the region with the agricultural sector which is the majority of the population's work. This is like what was found in the millennial generation in Padang Cekur Village, Ilir Talo District, Seluma District. Seeing this phenomenon raises the real question what is the perception of the millennial generation and the factors that influence the perceptions of farmer children in Padang Cekur Village, Ilir Talo District, Seluma District on work in the agricultural sector today.

\section{Research Methods}

This research was conducted in October 2018 December 2019 using a quantitative research approach supported by qualitative data. The measuring instrument used in collecting quantitative data is a questionnaire. While for qualitative data collection carried out through observation, as well as in-depth interviews with several informants. The data used in this study include primary data and secondary data. Primary data in the form of quantitative and qualitative data obtained from interview questionnaires, in-depth interviews, and direct observation to the village. While secondary data as supporting data obtained through literature in the form of documents relating to the topic of research. The limitations in the population studied were research in the village of padangurur which was restricted to the object of research, namely Millennial Generation of Farmer Children in Padang Cekur Village, Ilir Talo District, Seluma District. The population in this study was 944 people. To determine the sample size if the subject is less than 100 , it is better to take it all so that the research population. If the subject is larger it can be taken between $20-25 \%$ (Arikunto, 2002).

Based on observations in this study, the researcher determined this sampling using the Incidental Sampling method is a technique of determining the sample which is done based on coincidence or met with direct respondents who can be used as samples if deemed suitable as a data source. In determining the sample using the Taro Yamane formula quoted from Jamaluddin (2002: 82), namely.

Taro Yamane formula

$\mathrm{n}=\mathrm{N}$

$\mathrm{Nd} 2+1$

Description:

$\mathrm{n}=$ number of samples

$\mathrm{N}=$ total population

$\mathrm{d}=$ precision $(25 \%)$

$\mathrm{n}=944$

$944(0,25) 2+1$

$=944$

60

$\mathrm{n}=16$

So in this study the researcher took a sample of 16 respondents who were purposely appointed with the condition that the respondents wanted to be used as respondents and respondents were millennial generation of farmer children. 
Data analysis looked at the influence of internal and external factors on the perceptions of the millennial generation of peasant children in Padang Cekur Village, Ilir Talo District, Seluma District for agricultural work. By looking at the relationship between variables using non-parametric statistical tests through the Chi-Square test. Both variables are said to be related if the value of the test result ( $p$ value) is smaller than the value of $\alpha$ (alpha). In more detail to see the connection between variables explained as follows.

Hypothesis:

H0: both variables are not related

H1: Both variables are related

Test criteria:

Reject $\mathrm{H}_{0}$ if the value is $\mathrm{p}<\alpha$

Accept $\mathrm{H}_{0}$ if the value is $\mathrm{p}>\alpha$

When the results of $p$ values are smaller than alpha $(\alpha)$, then reject $\mathrm{H}_{0}$ means accept $\mathrm{H}_{1}$, which means the two variables have a relationship. Likewise vice versa, when the $\mathrm{p}$ value is greater than alpha $(\alpha)$, then $\mathrm{H}_{0}$ is accepted which means that the two variables are not related.

\section{Results And Discussion}

\section{a. Geographical Conditions}

Padang Cekur village is one of the villages from Ilir Talo District, Seluma District in Bengkulu Province, which is located in the western part of Sumatra Island, located in the western part of the Indonesian Ocean. The area of Bengkulu Province reaches 32,365.6 square kilometers. The province of Bengkulu extends from the border of West Sumatra Province to Lampung Province and the distance is approximately 567 kilometers. For the area of Padag Cekur Village with an area of 1400 hectares. The village climate is deserted, as other villages in the Indonesian region have dry and rainy weather, which has a direct influence on cropping patterns on agricultural land in Padang Cekur Village, Ilir Talo Subdistrict, Seluma District.

- The village of Padang Cekur is located in the area of Ilir Talo District, Seluma Regency,

- Bengkulu Province which borders:

- The north is bordered by Talang Kabu Village, Ilir Talo District.
- East side borders with Talang Panjang Village, Ilir Talo District.

- The south is bordered by Dusun Baru Village, Ilir Talo District.

- The west is bordered by Penago 1 Village, Ilir Talo District.

The area of padang cekur village is 1400 hectares, of which $70 \%$ is land used as agricultural land which is used for rice fields, yards and community plantations. The land use distribution in this village is the total area of padang cekur village of $1400 \mathrm{Ha}$, of which is filled by 35 hectares of rice fields or 2.5 percent, 1000 hectares of plantations or 71.42 percent, 200 hectares of land or 14.29 percent. and others covering $165 \mathrm{Ha}$ or 11.79. So it can be concluded that the widest area is used by 1000 hectares of plantations or $71.42 \%$ and the smallest area is used for 35 ha of rice fields or $2.5 \%$.

\section{b. Economic Status}

The economic situation of the people of Padang Cekur village in plain view is clearly the difference between households that are categorized as poor, very poor, moderate and rich. This is because the livelihoods are in different sectors of the business, most of them are non-formal sectors such as farmers, small businesses, housing for making snacks, baguanan workers, farm laborers, and in the formal sector such as local government officials, honorary staff, medical personnel, Police.

\section{c. Demographic Conditions}

Padang Cekur village has a population of 944 people, consisting of men: 480 people, women: 464 people and 280 families, which are divided into 3 (three) hamlets, and show that the composition of the population in Padang Cekur Village is at most found in Hamlet 1, with a composition of 170 inhabitants, 170 females with 97 families, and the smallest population of Padang Cekur Village in Hamlet 2 with 140 men, 267 females with 79 families.

\section{d. Level Of Education}

Education is one of the most important factors for the progress of an area, including in Padang Cekur Village. In the education of farmers according to the level of education in the village of Padang Cekur at most, the level of pre-school and high school is as many as 185 people $(37.15 \%)$ and at least the undergraduate education level of 35 people (7.02\%). This shows that the education of the residents of Padang Cekur village is relatively low. And the educational facilities in 
Padang Cekur village are still relatively low. Because there are only 1 elementary school unit and 1 unit education facility. This can lead to a lack of education levels in the Padang Cekur village community.

\section{e. Employment Situation.}

Padang Cekur villagers have jobs as farmers, ranchers, traders, small businesses, civil servants and laborers. The population of Padang Cekur Village who works according to the type of work in 2018 is as follows.

\section{f. Respondents by Age}

In this study the respondents who were taken were millennial generation, where the millennial generation according to the 2008 Baby Boom Population stated that the millennial generation was a generation born in 1980-2000. Which if calculated in 2018 this generation is $18-38$ years old. From the data obtained, it can be concluded that respondents aged 18-24 years amounted to 5 people or $31.25 \%$, respondents aged $25-$ 31 years amounted to 6 people or $37.5 \%$, and respondents aged over $32-38$ years amounted to 5 people or $31.5 \%$.

\section{g. Gender}

In this study researchers took $50 \%$ of male respondents and $50 \%$ of female respondents. And it can be concluded that the sex of the respondents studied was 8 men or with a percentage of $50 \%$ and the remaining $50 \%$ or 8 were women.

\section{h. Education}

From the data obtained, it can be concluded that from the highest age of 38 years old, this millennial generation, if those who attend school are graduates. And can show the education level of the respondent, namely elementary school 2 people or $12.5 \%$, junior high school 2 people or $12.5 \%$, high school 8 people or $50 \%$, and undergraduate 4 people or $25 \%$.

\section{i. Marital Status}

Herlina (2002) says that the millennial generation who are unmarried, do not have a big responsibility, he can still ask parents for daily needs. This resulted in the pressure to work still small so that it was still selective at work. As with the millennial generation who are married, economic pressure is a major factor in finding a job, the perception of finding a job is a source of money, so even though the job is not in demand, it will still be done. From table 6 , it can be concluded that there are 8 people who are married or $50 \%$ who are married and the respondents in this study who have not married are 8 people or $50 \%$.

\section{j. Skills}

From the data obtained, it can be concluded based on the skills showing that the skills of the respondents are still very lacking, of which 16 respondents 5 respondents or $31.25 \%$ of respondents have the skills and the remaining 11 respondents or $68.75 \%$ have no skills.

\section{k. Employment History}

From the data obtained, there were 9 respondents who worked or $56.25 \%$ and those who did not work 7 people or $43.75 \%$. Then respondents who have work experience have 5 people or $31.25 \%$ and those who do not have work experience there are 11 people or $68.75 \%$, then there are 9 respondents or $90 \%$ and 1 respondent who does not look for work after graduating from school. And it can be concluded that the millennial generation who is unmarried, does not have a large responsibility, he can still ask parents for daily needs.

This resulted in the pressure to work still small so that it was still selective at work. As with the millennial generation who are married, economic pressure is a major factor in finding a job, the perception of finding a job is a source of money, so even though the job is not attractive, it will still be worked on, then there are still many respondents who have no experience looking for work, and respondents who were looking for work after graduating there were 15 respondents or $93.75 \%$ and 1 respondent or $6.25 \%$ who did not look for work after graduating from school. From the table above, it can be concluded that the respondents in Padang Cekur village were on average directly looking for work after graduating from school, this was due to economic factors and married respondents' factors causing the respondents to work.

\section{External Factors}

External factors are factors that come from outside the individual, the condition or condition of someone who is influenced by their environment. In terms of the selection of work and perceptions of the millennial generation of villages on employment in the agricultural sector, external factors that influence the family's socio-economic status, job socialization and cosmopolitan level. 


\section{a. Socio-Economic Status}

From the research data, respondents' land ownership is based on having 2 people or $12.5 \%$ and the remaining 14 people or $87.5 \%$ do not have agricultural land, then if the respondent owns the land and there will be 4 people or $28,57 \%$ answered that they worked alone, 9 people or $64.29 \%$ answered that they were rented and 1 person or $7.14 \%$ answered for savings, from here it was seen that the millennial generation's interest in the agricultural sector was lacking because more than 50\% of respondents answered if they owned agricultural land then the land will be leased.

Then in the land ownership of the respondent's parents, all the parents of the respondents own agricultural land for oil palm plantations of 7 people or $43.75 \%$ and the fields have 9 people or $56.25 \%$, with a land area of 1 ha 13 people or $81.25 \%$ and the remaining 3 people or $18.75 \%$ with a land area of 2 ha which earns Rp. 1,000,000-1,400,000 5 people or $31.25 \%$, income of Rp. 1,500,000-1,900,000 6 people or $37.5 \%$, and 5 people or $31.25 \%$ earn Rp. $2,000,000-$ $2,500,0000$. and many respondents who do not own land, this is due to many of the respondents whose economic conditions are not good, this can be seen from the total income of the respondents 'old money and the area of land that the respondents' parents have, then based on the table above many respondents if they own land the land wants to be leased, we can conclude that there is still very little desire of respondents who want to work on agricultural land.

\section{b. Job Socialization}

From the research data, it can be concluded that the average respondent was introduced to the agricultural sector with his parents, obtained 14 people or $87.5 \%$ of respondents answered yes they were introduced to agriculture by their parents and the remaining 2 people or 12.5 answered that his parents had never been introduced to the agricultural sector. Then there are 14 people or $87.5 \%$ of the respondents' parents of the total number of respondents who can expect their children to work outside the agricultural sector and only 2 or $12.5 \%$ of parents of respondents who want their children to work in agriculture. It can be concluded that the respondents 'parents expect their children to work in the non-agricultural sector, this can be seen that only $12.5 \%$ of respondents' parents expect their children to work in the agricultural sector, of course this greatly affects a child's perception of finding a job.

\section{c. Cosmopolitan Level}

From the data of the research results, the number and percentage of respondents who have been in the city can be seen that of the 16 respondents who were speakers there were 10 people or $62.5 \%$ who had been cities and 6 or $37.5 \%$ were never cities, then based on table 10 it can be concluded that all respondents in this study had cellphones. And respondents who have smartphone phones have 11 people or $68.75 \%$ and 5 or $31.25 \%$ have ordinary cellphones. Can also be seen from the table above 9 people or $56.25 \%$ of the number of respondents like to access the internet and the remaining 7 people or $43.75 \%$ again do not like to access the internet. Of those who can access the internet 13 people or $81.25 \%$ and the remaining 3 people or $18.5 \%$ cannot access the internet. Then from the topic that respondents liked to access the internet the most was on online products where there were more than $50 \%$, namely $54.55 \%$. and on television access that respondents often see is on news programs and soap operas with the same ratio of $43.75 \%$. It can be concluded that the cosmopolitan level of the village community has also been higher. It can be seen that all respondents already have mobile phones and more than $50 \%$ can access the internet, of course this affects respondents' perceptions of agriculture. but even though respondents were able to access the internet but many of the respondents did not assess matters related to their work, for example in farming, many of the respondents did not find out the problems they faced on the internet and only used the internet as a medium to access FB, WA. not making the internet a source to deal with workers' problems.

\section{Perception Of Agriculture}

From the data from the research results, it was found that 12 people or $75 \%$ thought that employment in the agricultural sector was more tiring than nonagricultural jobs. Furthermore, 9 people or $56.25 \%$ found that income in the agricultural sector was smaller than non-agricultural. Then there are 9 people or $56.25 \%$ think the capital in the agricultural sector is greater than non-agricultural. Then there are 12 people or $75 \%$ who think that the right to work in the agricultural sector is the younger generation. And there are 5 people or $31.25 \%$ who think that it is suitable to work in the agricultural sector in terms of high school graduation education, and there are 5 people or $31.25 \%$ who think that it is suitable to work in the agricultural sector in terms of graduate education. It can be concluded that the respondents' perceptions of agriculture were relatively negative. It was seen that more than $50 \%$ of respondents were 
negative about agriculture, this was attributed to many of the respondents who thought that work in the agricultural sector was more tiring, income was small, wages were small, and time spent on the agricultural sector is also very long, this is what causes respondents to negatively regard the agricultural sector because of the experience gained in the environment.

\section{Analysis of Factors Affecting Millennial} Generation Perceptions of Agriculture

Based on the results (Dwi, 2009 in bilondatu, 2013) states that perception is a process that makes someone choose to organize and interpret accepted stimuli into a meaningful and complete picture of his world.

The results of testing with Gender variables on the Perceptions of Millennials of Farmer Children Against Work in the Agricultural Sector, the significance of the results from alpha which does not affect the perception of the millennials towards employment in the agricultural sector is greater. then on Skills, work experience, family economic status, job socialization, and cosmopolitan level, Against Perceptions of Millennials of Farmer Children Against Work in the Agricultural Sector got a smaller significance than alpha which means skills, work experience, family economic status, job socialization and the cosmopolitan level, affecting the millennials perception of employment in the agricultural sector.

\section{Conclusion}

Perception of Millennial Generation of Farmers 'Children in Padang Cekur Village, Ilir Talo District, Seluma District on the work in the agricultural sector was negative, due to the lack of motivation given by respondents' parents to agricultural work and due to the expectation of parents who wanted their children to work outside the agricultural sector. Factors that influence the millennial generation towards the perception of employment in the agricultural sector are skills, work experience, family socio-economic status, job socialization, and cosmopolitan level.

\section{References}

Arikunto, 2002. Population, sample, sample size and sampling technique. [Internet].[quoted December 10, 2018]. Available from http://villavava.blogspot.com/2014/07/populasisampel-besar-sampel-dan-teknik.html? M = 1

Bilondatu, Macharani Rinandha. 2013. Motivation, Perception, and Trust in Its Effect on Consumer
Purchasing Decisions on Yamaha Motorbikes in Minahasa. Journal of EMBS, 1: 710-720.

Baby Boom Population - U.S. Census Beureau - USA and by State (1 July 2008). [Internet]. [quoted October 10, 2018]. Can be downloaded from https: //."Baby Boom Population-U.S.Census Beureau USA and by State (1 July 2008) ".

[BPS]. Central Bureau of Statistics. 2010. Population by age and sex [internet]. [Follow 22 September 2018]Available from: http: //sp2010.bps.go.id/index. $\mathrm{php} / \mathrm{site} /$ Table? $\mathrm{tid}=336 \& \mathrm{wid}=0$

[Depnakertrans] Ministry of Manpower and Transmigration. 2012. Residents who work according to age group and business field. [Internet]. [quoted September 22, 2018]. Available from:pusdatinaker.balitfo.depnakertrans. go.id/?section=pyb\&period=2012-02-01\#goto

Period Herlina. 2002. Orientation of the value of youth work to plantation farming families.[thesis].

[Internet]. [quoted September 22, 2018]. Available from: http://repository.ipb.ac.id/ bitstream/handle/123456789/6810/ 2002her1.pdf? Sequence $=$ Ina M. 2002. Perception.

[Internet]. Can be downloaded from: http: //eprints.uny.ac.id/9686/3/chapter\%202.pdf

Prihatmoko H.2013. The number of workers in the agricultural sector continues to decline. [Internet]. [quoted September 22,2018]. Can be downloaded from:http://www.bisnis.com/m/employment,worke rs-in-agriculture-sector continues to decline. 